\title{
Nitrogen supply associated with the application of trinexapac-ethyl in upland rice irrigated by sprinkler
}

\section{Fornecimento de nitrogênio associado a aplicação de etil-trinexapac em arroz de terras altas irrigado por aspersão}

\author{
Igor Balbi Guirão Peron ${ }^{1}$; José Roberto Portugal2*; Orivaldo Arf ${ }^{3}$; Ricardo Antônio \\ Ferreira Rodrigues ${ }^{3}$; Douglas de Castilho Gitti ${ }^{4}$
}

\begin{abstract}
The lodging of rice plants significantly increases the losses of this crop. Lodging is caused by the inadequate management of water and fertilizers, particularly nitrogenous fertilizers. The use of growth regulators causes a reduction in plant height and consequently lodging, and may reduce harvest losses. The objective of this study was to evaluate nitrogen $(\mathrm{N})$ doses with and without application of plant growth regulator in upland rice irrigated by a sprinkler system. The experimental design consisted of randomized blocks arranged in a $4 \times 2$ factorial design with four replicates. The treatments consisted of four $\mathrm{N}$ doses $\left(0,40,80\right.$, and $\left.120 \mathrm{~kg} \mathrm{ha}^{-1}\right)$ combined with the presence or absence of foliar application of a plant growth regulator. The application of $150 \mathrm{~g} \mathrm{ha}^{-1}$ of trinexapac-ethyl at the flower differentiation stage reduced plant height and lodging. In addition, this treatment promoted increased 100-grain mass. The use of $\mathrm{N}$ doses in topdressing increased plant heights and grain yield. The plant growth regulator did not interfere with the milling yield of upland rice. Nitrogen fertilization in the topdressing did not interfere with the milling yield of upland rice irrigated by a sprinkler system.
\end{abstract}

Key words: Oryza sativa L. Lodging. Nitrogen fertilization. Plant growth regulator.

\section{Resumo}

O acamamento das plantas de arroz aumenta sensivelmente as perdas dessa cultura, que é ocasionado pelo fornecimento de água e fertilizantes, principalmente os nitrogenados, manejados de forma inadequada. $\mathrm{O}$ uso de reguladores vegetais propicia redução na altura de plantas e consequentemente no acamamento, podendo minimizar as perdas na colheita. O objetivo foi avaliar doses de nitrogênio (N) com e sem a aplicação de regulador vegetal em arroz de terras altas irrigado por aspersão. $\mathrm{O}$ delineamento experimental utilizado foi o de blocos casualizados, disposto em esquema fatorial $4 \times$ 2 , com quatro repetições. Os tratamentos foram constituídos por quatro doses de $\mathrm{N}$ em cobertura $(0$, 40,80 e $120 \mathrm{~kg} \mathrm{ha}^{-1}$ ) combinadas com ou sem aplicação de regulador vegetal. A aplicação de $150 \mathrm{~g}$ $\mathrm{ha}^{-1}$ de etil-trinexapac, por ocasião da diferenciação floral, reduz a altura de plantas e o acamamento, e promove aumento da massa de 100 grãos. O uso de doses de $\mathrm{N}$ em cobertura aumenta a altura de plantas e incrementa a produtividade de grãos. $O$ regulador vegetal interfere pouco no rendimento de engenho do arroz de terras altas. A adubação nitrogenada em cobertura praticamente não interfere no rendimento

${ }^{1}$ Eng $^{\circ}$ Agr $^{\circ}$, Bunge, Chapadão do Céu, GO, Brasil. E-mail: igorbguirao@hotmail.com

2 Discente de Doutorado em Agronomia, Faculdade de Engenharia de Ilha Solteira, UNESP, Ilha Solteira, SP, Brasil. E-mail: jrp. agrunesp@gmail.com

3 Profs. Drs., Faculdade de Engenharia de Ilha Solteira, UNESP, Ilha Solteira, SP, Brasil. E-mail: arf@agr.feis.unesp.br; ricardo@, agr.feis.unesp.br

4 Eng $^{\circ}$ Agr $^{\circ}$, Dr., Pesquisador, Fundação MS, Maracajú, MS, Brasil. E-mail: douglas@fundacaoms.org.br

* Author for correspondence

Received: Mar. 27, 2018 - Approved: June 18, 2019

Semina: Ciências Agrárias, Londrina, v. 40, n. 5, suplemento 1, p. 2137-2150, 2019 
de engenho do arroz de terras altas irrigado por aspersão.

Palavras-chave: Oryza sativa L. Acamamento. Adubação nitrogenada. Regulador vegetal.

\section{Introduction}

Rice (Oryza sativa L.) plays an important role in food security for most of the world's population (LIU et al., 2016; LOPES et al., 2013), serving as a source of calories and proteins (CONTRERAS et al., 2017). Therefore, the production of this cereal has been increasing at the same rate as that of the population (REIS et al., 2018). In Brazil, rice is one of the main annual crops and is cultivated in all regions and in various environments (BARRETO et al., 2012). Rice cultivation is carried out under both a flood irrigation system, which comprises the major part of the area and of production, and under an upland system, either dry or irrigated by sprinkler, located mainly in the Cerrado region.

Owing to concerns about world water shortages, especially in agriculture, a well-targeted option in some parts of the world is rice production in the upland system, since it has potential for water savings (PORTUGAL et al., 2015b).

The use of irrigation in an upland rice system can lead to an increase in the level of technology applied (ARF et al., 2012), particularly the use of inputs, of which nitrogen is primary. Nitrogen is essential for plant growth and development, and is removed by rice cultivation, which requires approximately 15 $\mathrm{kg}$ for the production of one ton of grains in straw (BASUCHAUDHURI, 2016). In addition, $\mathrm{N}$ is one of the most limiting nutrients for rice production in the Brazilian Cerrado (FAGERIA et al., 2014). Nitrogen fertilization is directly related to increased productivity and improved rice grain quality (NASCIMENTO etal., 2013). The application of this nutrient leads to an increase in plant height, number of panicles, number of spikelets, and number of full spikelets, which largely determine the productive capacity of a rice plant (BASUCHAUDHURI, 2016). However, the application of excess nitrogen causes high vegetative growth, causing lodging of the plants (ARF et al., 2012; NASCIMENTO et al., 2013; FAGERIA, 2007; BUZETTI et al., 2006) and making mechanized harvest difficult (ARF et al., 2012).

One possible way to reduce plant height, and consequently lodging, is the application of plant regulators (NASCIMENTO et al., 2009), which in addition to decreasing plant height provide better utilization of nutrients under the physiological changes exerted on the plants (BUZETTI et al., 2006). The application of plant regulators such as trinexapac-ethyl can increase the quality and quantity of rice grains, especially in regions with high winds (NA et al., 2011). The use of plant regulators in upland rice cultivation with sprinkler irrigation leads to a considerable reduction in plant height, and might be an excellent alternative for rural producers who employ higher levels of technology, such as irrigation and nitrogen fertilization, to help them avoid plant lodging (ALVAREZ et al., 2014).

The objective of this study was to study $\mathrm{N}$ dose combinations, with and without a plant regulator, in order to solve the problem of losses due to lodging without a significant decrease in the yield and quality of upland rice grains irrigated by sprinkler.

\section{Materials and Methods}

The work was conducted in the agricultural years of 2007/2008, 2008/2009, and 2009/2010 in an experimental area belonging to the Faculty of Engineering - UNESP, Ilha Solteira Campus, located in the municipality of Selvíria - MS, at approximately $51^{\circ} 22^{\prime} \mathrm{W}$ and $20^{\circ} 22^{\prime} \mathrm{S}$, with an altitude of $335 \mathrm{~m}$. The soil in the experimental area is a typical red clayey Latosol (SANTOS et al., 2013). During the conduction of the experiment, soil samples were collected in the $0.0-0.20 \mathrm{~m}$ layer in order to characterize the chemical attributes (Table 1). 
Table 1. Soil chemical attributes evaluated in the layer of 0.0 a $0.20 \mathrm{~m}$.

\begin{tabular}{|c|c|c|c|c|c|c|c|c|c|c|}
\hline \multirow[t]{2}{*}{ Year } & P resin & $\mathrm{OM}$ & $\mathrm{pH}$ & K & $\mathrm{Ca}$ & $\mathrm{Mg}$ & $\mathrm{H}+\mathrm{Al}$ & $\mathrm{Al}$ & \multirow[t]{2}{*}{ CEC } & \multirow{2}{*}{$\begin{array}{l}\mathrm{BS} \\
(\%)\end{array}$} \\
\hline & $\mathrm{mg} \mathrm{dm}^{-3}$ & $\mathrm{~g} \mathrm{dm}^{-3}$ & $\mathrm{CaCl}_{2}$ & & ----. & & $\mathrm{mol}_{\mathrm{c}} \mathrm{dm}$ & - & & \\
\hline $2007 / 08$ & 28 & 13 & 4.9 & 3.1 & 16 & 4 & 20 & 0 & 43 & 54 \\
\hline 2008/09 & 17 & 13 & 5.2 & 2.9 & 33 & 14 & 27 & 0 & 77 & 65 \\
\hline $2009 / 10$ & 28 & 22 & 4.5 & 4.0 & 14 & 8 & 46 & 1 & 72 & 36 \\
\hline
\end{tabular}

The average annual rainfall is $1313 \mathrm{~mm}$, with a mean annual minimum temperature of $19{ }^{\circ} \mathrm{C}$ and mean annual maximum temperature of $31^{\circ} \mathrm{C}$ (PORTUGAL et al., 2015a). The climate of the region, according to the Köppen classification, is Aw, defined as humid tropical, with a rainy season in summer and dry season in winter. During the experimental period, which consisted of the years 2007/2008, 2008/2009, and 2009/2010, data were collected on rainfall and minimum and maximum air temperature (Figure 1).

Figure 1. Daily variation in rainfall and maximum and minimum air temperatures during the conduction of the experiments. Selvíria - MS, (A) 2007/08, (B) 2008/09 and (C) 2009/10.
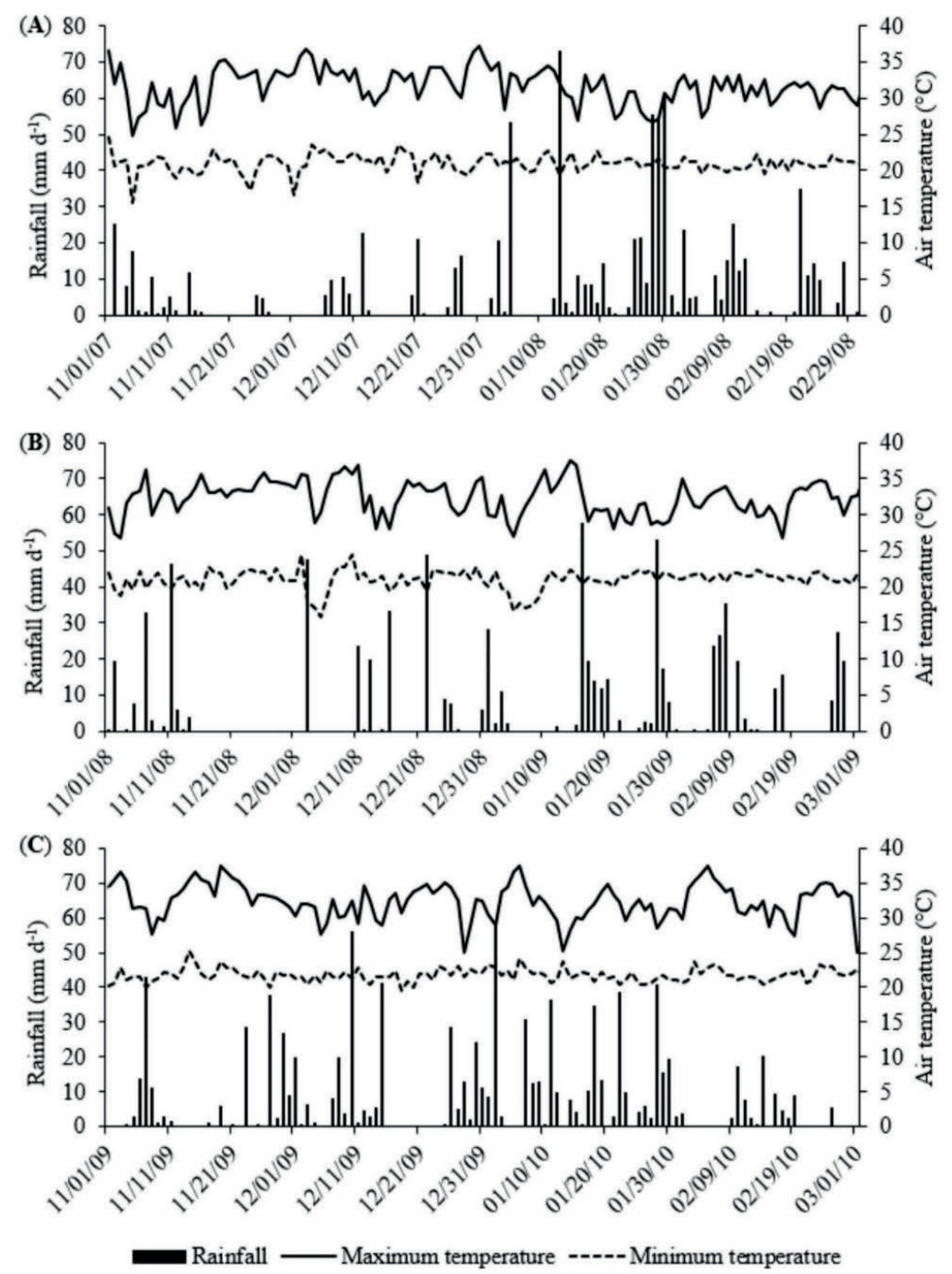
The cultivar used was BRS Primavera, which had the following characteristics: medium size (100-120 cm), short cycle (112 days), 80 days from emergence to flowering, fine long grain (needle), and moderately susceptible to blast (Pyricularia oryzaea Cav.) and lodging (BRESEGHELLO et al., 1998).

The experimental design was a randomized block design, arranged in a $4 \times 2$ factorial scheme with four replications. The plots constituted seven rows of $5.0 \mathrm{~m}$ in length, spaced $0.34 \mathrm{~m}$ apart. The usable area was comprised of the five central rows, being despised $0.50 \mathrm{~m}$ from both ends of each line.

The treatments consisted of four doses of $\mathrm{N}$ in the topdressing $\left(0,40,80\right.$, and $\left.120 \mathrm{~kg} \mathrm{ha}^{-1}\right)$ with and without application of plant regulator (trinexapacethyl). The topdressing $\mathrm{N}$ was applied manually at 30 days after plant emergence, using urea as a source. Soon after the application, in the first and second year, irrigation was used with a water slide of 8-10 mm, and in the third year of cultivation, after the application of $\mathrm{N}$, rainfall of $10.7 \mathrm{~mm}$ occurred.

Correction and fertilization were performed, taking into account the chemical characteristics of the soil (Table 1). In the third year of cultivation, liming was performed at $1.5 \mathrm{tha}^{-1}$ to raise the base saturation to $50 \%$. Subsequently, a heavy gradation and two lighter gradations were performed. The mineral fertilization at sowing was $180 \mathrm{~kg}$ $\mathrm{ha}^{-1} 08-28-16+\mathrm{Zn}+\mathrm{Ca}+\mathrm{S}$, according to the recommendations of Cantarella et al. (1997), aiming at a productivity of between 4.0 and $6.0 \mathrm{tha}^{-1}$.

Sowing was carried out mechanically on November 5 in 2007 and 2009. In 2008, sowing was performed on November 6, using the amount of seeds needed to obtain 180 plants $\mathrm{m}^{-2}$.

The seeds were treated with thidocarb $(300 \mathrm{~g}$ of active ingredient (a.i.) + zinc oxide $(250 \mathrm{~g}$ a.i. $)+$ molybdenum (10 g a.i.) + boron (2 $g$ a.i.) for each $100 \mathrm{~kg}$ of seeds). Soon after sowing, the application of pre-emergence pendimethalin (1400 $\mathrm{g} \mathrm{ha}^{-1}$ a.i.) was performed, with a flow rate of $130 \mathrm{~L} \mathrm{ha}^{-1}$.
The plant regulator trinexapac-ethyl was applied at the time of differentiation of the panicle primordium at a dose of $150 \mathrm{~g} \mathrm{ha}^{-1} \mathrm{a}$ a... The application was carried out in the form of a directed jet, with a costal spray volume of approximately $460 \mathrm{~L} \mathrm{ha}^{-1}$. The plant regulator applications were performed in the morning, with a wind speed between 0.0 and $1.0 \mathrm{~m} \mathrm{~s}^{-1}$ and $90 \%$ relative humidity. Even with the conditions being optimal for the application, a bulkhead was used to avoid drift to other plots.

The water supply was a fixed sprinkler irrigation system with a mean precipitation of $3.3 \mathrm{~mm} \mathrm{~h}^{-1}$ from the sprinklers. The precipitation was determined using a Ville de Paris rain gauge installed near the experimental area, which accumulated $695 \mathrm{~mm}$ in the first year, $636 \mathrm{~mm}$ in the second year, and 776 $\mathrm{mm}$ in the third year. For water management, up to three crop coefficients $(\mathrm{Kc})$ were used, distributed over four periods between emergence and harvest. For the vegetative phase, a value of 0.4 was used; for the reproductive phase, two cultivation coefficients $(\mathrm{Kc})$ were used, an initial value of 0.70 and final value of 1.00; and for the maturation phase, these values were inverted; that is, an initial value of 1.00 and final value of 0.70 .

Rice flowering occurred at 70 DAE the first and third year and 74 DAE in the second year. Harvest was performed at 102, 104, and 94 DAE in the first, second, and third year, respectively.

During the experimental period, the foliar $\mathrm{N}$ content was evaluated. At flowering time, the foliar leaf blades of 50 leaves per plot were collected, dried, and then ground in a Wiley mill before sulfuric digestion. Plant height during the grain stage in the pasty form was determined in 10 plants at random. The mean distance was determined from the soil surface to the upper end of the highest panicle. Degree of lodging was obtained through visual observations during the maturation phase using the following scale: $0=$ no lodging; $1=$ up to $5 \%$ of plant lodged; $2=5$ to $25 \%, 3=25$ to $50 \%$; $4=50$ to $75 \%$; and $5=75$ to $100 \%$ lodged plants. 
The production and productivity components evaluated were number of stems per square meter, determined by counting the number of stems in a 1.0 $m$ row of plants and then calculated per square meter; number of panicles per square meter, determined by counting the number of panicles in $1.0 \mathrm{~m}$ of plants and later calculated per square meter; total number of spikelets per panicle, obtained by counting the number of spikelets of 20 panicles collected at the time of harvest; number of full and empty spikelets per panicle, determined by counting the number of full and empty spikelets of 20 panicles after separating them by air flow; 100-grain weight, evaluated by random sampling and weighing two samples of 100 grains of each plot (13\% wet basis); and grain yield, determined by weighing the paddy grain coming from the useful area of the plot, after correcting the humidity to $13 \%$ and converting to $\mathrm{kg} \mathrm{ha}^{-1}$.

The milling yield evaluation was performed by collecting a sample of $100 \mathrm{~g}$ of rice grains in each plot portion, which was processed into test mill for 1 min; the polished grains were then weighed and the results considered as the milling yield, expressed as a percentage. Later, the polished grains were placed in a Trieur No. 2 and the grain separation was processed for $30 \mathrm{~s}$; the grains that remained in the Trieur were weighed to obtain the head yield and the remaining grains broken, both expressed as a percentage.

The results were submitted to the ANOVA F-test. A significant result was verified by the F-test ( $p \leq$ 0.01 and $p \leq 0.05)$, and a Tukey test $(p \leq 0.05)$ was performed on the growth regulator and polynomial regression of $\mathrm{N}$.

\section{Results and Discussion}

The application of the growth regulator caused a reduction of $14.7 \mathrm{~cm}$ in plant height, and thus resulted in the absence of lodging (Table 2). Plant growth retardants act by inhibiting the biosynthesis of gibberellin (DAVIES, 1995), a hormone that, among other actions, promotes cell growth (TAIZ et al., 2017). With the application of $150 \mathrm{~g} \mathrm{ha}^{-1}$ of trinexapac-ethyl during floral differentiation, Arf et al. (2012); Castilho et al. (2012); Ferrari et al. (2017), and Nascimento et al. (2009) reported a mean reduction of $16,20,27$, and $40 \mathrm{~cm}$ in the height of rice plants. Along with these reductions in plant height, the authors describe the absence of plant lodging. The use of highly technological practices in rice cultivation can stimulate the exaggerated development of some cultivars, causing lodging, which hampers mechanized harvesting (ARF et al., 2012). Thus, the use of trinexapacethyl in rice cultivation leads to a reduction in plant height, reducing lodging and improving the quality of the grain harvest by maximizing the productive potential.

In the second year, the height of the plants adjusted to the quadratic model with the doses of $\mathrm{N}$, obtaining maximum height with approximately 110 $\mathrm{kg} \mathrm{ha}^{-1}$ of $\mathrm{N}$. In the third year, the data were adjusted to the linear model with the addition of $\mathrm{N}$. In the second year, the soil had a lower acidity level than in the third year (Table 1); thus, in the second year there could have been greater $\mathrm{N}$ availability from the mineralization of soil organic matter (SOM), causing a lesser response to the increase in nitrogen fertilization. According to Freire et al. (2001), there is a reduction in organic nitrogen mineralization with decreasing soil $\mathrm{pH}$, which is caused by the microorganisms responsible for this process. Silva et al. (1999) studied the mineralization of $\mathrm{N}$ by liming in seven types of soils, and concluded that this practice (increase in $\mathrm{pH}$ ) promotes acceleration of nitrogen mineralization in Glei Humic soil and Red-Yellow Latosol. 
Table 2. Height of plants, degree of lodging, and $\mathrm{N}$ content obtained in upland rice with growth regulator and nitrogen doses. Selvíria (MS), 2007/08, 2008/09, and 2009/10.

\begin{tabular}{lccccccccc}
\hline \multirow{2}{*}{ Treatments } & \multicolumn{3}{c}{ Height of plants $(\mathrm{m})$} & \multicolumn{3}{c}{ Lodging $^{1}$} & \multicolumn{3}{c}{$\mathrm{N}$ content $\left(\mathrm{g} \mathrm{kg}^{-1}\right)$} \\
\cline { 2 - 10 } & $07 / 08$ & $08 / 09$ & $09 / 10$ & $07 / 08$ & $08 / 09$ & $09 / 10$ & $07 / 08$ & $08 / 09$ & $09 / 10$ \\
\hline Regulator & & & & & & & & & \\
Without & $1.2 \mathrm{a}$ & $1.05 \mathrm{a}$ & $1.2 \mathrm{a}$ & $2.8 \mathrm{a}$ & 1.1 & $1.9 \mathrm{a}$ & 30.1 & $28.7 \mathrm{~b}$ & 30.3 \\
With & $1.1 \mathrm{~b}$ & $0.87 \mathrm{~b}$ & $1.0 \mathrm{~b}$ & $0.0 \mathrm{~b}$ & 0.4 & $0.0 \mathrm{~b}$ & 31.4 & $30.8 \mathrm{a}$ & 30.4 \\
\hline LSD & 0.04 & 4.70 & 0.05 & 1.06 & 0.31 & 0.27 & 1.64 & 1.47 & 1.13 \\
\hline $\mathrm{N}$ doses $\left(\mathrm{kg} \mathrm{ha}^{-1}\right)$ & & & & & & & & & \\
0 & 1.1 & $0.8^{2}$ & $1.1^{3}$ & 1.4 & $0.5^{4}$ & 0.4 & $28.4^{5}$ & $27.0^{6}$ & $28.5^{7}$ \\
40 & 1.1 & 0.9 & 1.1 & 1.4 & 0.5 & 0.8 & 30.1 & 27.8 & 30.0 \\
80 & 1.1 & 1.0 & 1.2 & 1.8 & 0.8 & 1.1 & 31.4 & 31.3 & 30.6 \\
120 & 1.1 & 1.0 & 1.2 & 1.3 & 1.3 & 1.5 & 33.0 & 32.9 & 32.3 \\
\hline $\mathrm{F}$ test & & & & & & & & & \\
$\mathrm{R}$ & $17.85^{* *}$ & $64.99^{* *}$ & $49.36^{* *}$ & $30.23^{* *}$ & $17.35^{* *}$ & $205.43^{* *}$ & $2.67^{\text {ns }}$ & $8.60^{* *}$ & $0.01^{\text {ns }}$ \\
$\mathrm{N}$ & $2.10^{\text {ns }}$ & $15.14^{* *}$ & $4.03^{*}$ & $0.19^{\text {ns }}$ & $5.43^{* *}$ & $13.70^{* *}$ & $6.12^{* *}$ & $15.85^{* *}$ & $8.19^{* *}$ \\
$\mathrm{R} \times \mathrm{N}$ & $0.41^{\text {ns }}$ & $0.63^{\text {ns }}$ & $0.25^{\text {ns }}$ & $0.29^{\text {ns }}$ & $3.09^{\text {ns }}$ & $13.70^{* *}$ & $0.49^{\text {ns }}$ & $1.78^{\text {ns }}$ & $1.90^{\text {ns }}$ \\
\hline $\mathrm{CV}(\%)$ & 4.69 & 6.69 & 6.33 & 39.61 & 18.43 & 39.47 & 7.24 & 6.73 & 5.05 \\
\hline
\end{tabular}

Mean values followed by the same letters are equivalent, based on the Tukey test at $5 \%$ of probability.

ns - not significant, $*$ and $* *$ significant at $5 \%$ and $1 \%$ of probability, respectively. LSD - least significant difference by Tukey test.

(1) For the statistical analysis, data were transformed into $\sqrt{\mathrm{x}}+0.5$.

(2) $\hat{y}=0.836+0.00348 x-0.000016 x^{2}\left(R^{2}=0.99\right)$.

(3) $\hat{y}=1.078+0.0009 x\left(R^{2}=0.99\right)$.

(4) $\hat{\mathrm{y}}=0.907+0.0028 \mathrm{x}\left(\mathrm{R}^{2}=0.82\right)$.

(5) $\hat{y}=28.461+0.0377 x\left(R^{2}=1.00\right)$.

(6) $\hat{y}=26.549+0.0532 x\left(R^{2}=0.95\right)$.

(7) $\hat{y}=28.572+0.0296 x\left(R^{2}=0.97\right)$.

With increasing doses of $\mathrm{N}$ in the second year, there was also an increase in the lodging rate of the rice plants. This characteristic is directly related to the height of the plants, so in the second year, the height of plants with the application of $120 \mathrm{~kg} \mathrm{ha}^{-1}$ of $\mathrm{N}$ was $0.19 \mathrm{~m}$ greater when compared with those without topdressing fertilization. This response decisively increased lodging. According to Gitti et al. (2012), the height and the lodging of rice plants respond in a positive linear way to increasing $\mathrm{N}$ doses. In the absence of the application, there is less lodging of plants; thus, $\mathrm{N}$ directly influences this characteristic (ARF et al., 2015).

In the third year of the experiment, there was an interaction between the use of the regulator and the doses of $\mathrm{N}$ (Table 3). Regardless of the dose applied, in the presence of the regulator, there was no lodging of the rice plants. The opposite happened in the absence of the regulator. In the case of nonapplication of the growth regulator, the linear function was adjusted by increasing the $\mathrm{N}$ dose. Based on this information, it can be inferred that the increment of $\mathrm{N}$ for upland rice cultivation of the intermediate group (BRS Primavera), increased the lodging of the plants, and this problem could be solved by the application of $150 \mathrm{~g} \mathrm{ha}^{-1}$ of trinexapacethyl at floral differentiation. Nascimento et al. (2009) and Arf et al. (2012) reported that the use of $150 \mathrm{~g} \mathrm{ha}^{-1}$ of trinexapac-ethyl eliminated the problem of rice lodging in the BRS Primavera cultivar. 
Table 3. Development of significant interactions of analysis of variance related to plant lodging. Selvíria (MS). 2009/10.

\begin{tabular}{|c|c|c|c|c|c|}
\hline \multirow[b]{3}{*}{ Regulator } & \multicolumn{5}{|c|}{ Lodging $^{1}$} \\
\hline & \multicolumn{5}{|c|}{$\mathrm{N}$ doses $\left(\mathrm{kg} \mathrm{ha}^{-1}\right)$} \\
\hline & 0 & 40 & 80 & 120 & \\
\hline & \multicolumn{5}{|c|}{ 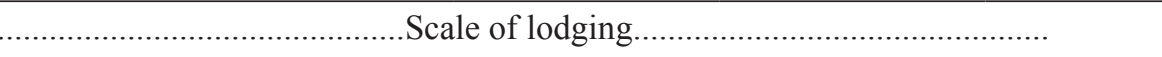 } \\
\hline With & $0.0 \mathrm{~b}$ & $0.0 \mathrm{~b}$ & $0.0 \mathrm{~b}$ & $0.0 \mathrm{~b}$ & ns \\
\hline Without & $0.8 \mathrm{a}$ & $1.5 \mathrm{a}$ & $2.2 \mathrm{a}$ & $3.0 \mathrm{a}$ & $\mathrm{LR}^{* *(2)}$ \\
\hline
\end{tabular}

Mean values followed by the same letters are equivalent, based on the Tukey test at $5 \%$ of probability.

ns - not significant, * and $* *$ significant at $5 \%$ and $1 \%$ of probability, respectively.

(1) Scale of values for lodging: 0 - without lodging; 1 - up to $5 \%$ of lodged plants; 2 - $5 \%$ to $25 \% ; 3-25 \%$ to $50 \%$; 4 - $50 \%$ to $75 \%$ and $5-75 \%$ to $100 \%$. For the statistical analysis, data were transformed into $\sqrt{x}+0.5$.

(2) $\hat{y}=0.7500+0.0188 x\left(R^{2}=1.00\right)$.

Leaf $\mathrm{N}$ content in the second year was higher by $2.1 \mathrm{~g} \mathrm{~kg}^{-1}$ dry matter with the application of the plant regulator (Table 2). $\mathrm{N}$ is the main constituent of the chlorophyll molecule, so it can be inferred that with higher $\mathrm{N}$ content, there is also a higher chlorophyll index, which is related to green leaf color. According to Davies (1995), growth retardants are a diversified group of synthetic compounds which generally increase the green color of leaves.

With increasing $\mathrm{N}$ supply, the nutrient content in the rice leaves was increased in the three years of the experiment. In the mean of the years, for each $\mathrm{kg}$ of $\mathrm{N}$ applied there was an increase of $0.04 \mathrm{~g}$ of $\mathrm{N} \mathrm{kg}^{-1}$ of dry leaf mass. According to Cazetta et al. (2008), the elevation of $\mathrm{N}$ content in the plant tissue is a result of the greater availability of the element in the soil. Similar results were found by Cazetta et al. (2008), Gitti et al. (2012), and Lopes et al. (2013).

The use of trinexapac-ethyl induced an increase of 30 stems per $\mathrm{m}^{2}$ in relation to the plants in the treatment without the regulator in the first agricultural year (Table 4). With the reduction in height of the plants caused by the application of the regulator, there was potentially a better hormonal balance that resulted in plants with a greater number of stems. According to Arf et al. (2012), the concentration of auxin in the main stem can influence the emission of tillers. Taller plants can cause shading of the lower leaves of the plant; according to Fornasieri Filho and Fornasieri (2006), the greater accumulation of auxin increases apical dominance, which reduces the development of the buds. Nascimento et al. (2009) and Arf et al. (2012) reported that with application of $150 \mathrm{~g} \mathrm{ha}^{-1}$ of trinexapac-ethyl, there was an increase of 47 and 72 stems $\mathrm{m}^{-2}$, respectively.

Regarding the $\mathrm{N}$ dose, in the second year, the number of stems $\mathrm{m}^{-2}$ was adjusted to the positive linear function. According to the equation, with the application of each $\mathrm{kg}$ of $\mathrm{N}$, there was an increase

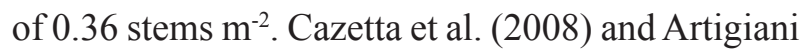
et al. (2012) verified an increase of 0.36 and 0.47 stems $\mathrm{m}^{-2}$, respectively, for each $\mathrm{kg}$ of $\mathrm{N}$ applied to cover in upland rice irrigated by sprinkler systems. The number of panicles $\mathrm{m}^{-2}$ was not altered by the treatments submitted (Table 4).

In the third year, the application of the growth regulator favored a larger number of spikelets per panicle (Table 5). However, during the three years there was an average reduction of $26 \%$ in the number of empty spikelets with the use of the regulator. The application of trinexapac-ethyl reduced the height of the plants, allowing greater and/or better transportation of photosynthates to fill the spikelets and reducing the number of empty ones. Castilho et al. (2012), studying the presence and absence of trinexapac-ethyl and sowing 
densities, verified a mean reduction of $33 \%$ in the a better distribution of photoassimilates, previously number of empty spikelets with the application of destined for the exaggerated development of the the regulator. According to these authors, there was plants, to the filling of spikelets.

Table 4. Mean values of number of stalk per $\mathrm{m}^{2}$ and number of panicles per $\mathrm{m}^{2}$ obtained in upland rice with growth regulator and nitrogen doses. Selvíria (MS), 2007/08, 2008/09, and 2009/10.

\begin{tabular}{|c|c|c|c|c|c|c|}
\hline \multirow{2}{*}{ Treatments } & \multicolumn{3}{|c|}{ Number of stalk per $\mathrm{m}^{2}$} & \multicolumn{3}{|c|}{ Number of panicles per $\mathrm{m}^{2}$} \\
\hline & 07/08 & $08 / 09$ & $09 / 10$ & $07 / 08$ & $08 / 09$ & $09 / 10$ \\
\hline \multicolumn{7}{|l|}{ Regulator } \\
\hline With & $247 \mathrm{~b}$ & 299 & 225 & 227 & 277 & 203 \\
\hline Without & $277 \mathrm{a}$ & 319 & 230 & 243 & 268 & 208 \\
\hline LSD & 29.87 & - & 17.80 & - & - & 12.68 \\
\hline \multicolumn{7}{|c|}{$\mathrm{N}$ doses $\left(\mathrm{kg} \mathrm{ha}^{-1}\right)$} \\
\hline 0 & 284 & $274^{1}$ & 221 & 259 & 248 & 200 \\
\hline 40 & 273 & 316 & 219 & 225 & 293 & 199 \\
\hline 80 & 233 & 326 & 231 & 212 & 283 & 215 \\
\hline 120 & 258 & 319 & 240 & 244 & 265 & 207 \\
\hline \multicolumn{7}{|l|}{ F test } \\
\hline $\mathrm{R}$ & $4.31^{*}$ & $2.30^{\mathrm{ns}}$ & $0.48^{\mathrm{ns}}$ & $1.91^{\mathrm{ns}}$ & $0.37^{\mathrm{ns}}$ & $0.78^{\text {ns }}$ \\
\hline $\mathrm{N}$ & $2.37^{\mathrm{ns}}$ & $3.30^{*}$ & $1.28^{\mathrm{ns}}$ & $3.38^{\mathrm{ns}}$ & $1.96^{\mathrm{ns}}$ & $1.46^{\mathrm{ns}}$ \\
\hline $\mathrm{R} \times \mathrm{N}$ & $1.26^{\mathrm{ns}}$ & $1.71^{\mathrm{ns}}$ & $1.32^{\mathrm{ns}}$ & $0.89^{\text {ns }}$ & $1.95^{\text {ns }}$ & $2.23^{\text {ns }}$ \\
\hline CV $(\%)$ & 15.52 & 11.90 & 10.64 & 13.73 & 14.76 & 8.39 \\
\hline
\end{tabular}

Mean values followed by the same letters are equivalent, based on the Tukey test at $5 \%$ of probability.

ns - not significant, $*$ and $* *$ significant at $5 \%$ and $1 \%$ of probability, respectively. LSD - least significant difference by Tukey test. (1) $\hat{\mathrm{y}}=287.3625+0.3591 \times\left(\mathrm{R}^{2}=0.62\right)$.

Table 5. Mean values of total spikelets, full spikelets, and empty spikelets per panicle obtained in upland rice with growth regulator and nitrogen doses. Selvíria (MS), 2007/08, 2008/09, and 2009/10.

\begin{tabular}{|c|c|c|c|c|c|c|c|c|c|}
\hline \multirow{2}{*}{ Treatments } & \multicolumn{3}{|c|}{ Total spikelets } & \multicolumn{3}{|c|}{ Full spikelets } & \multicolumn{3}{|c|}{ Empty spikelets } \\
\hline & $07 / 08$ & $08 / 09$ & $09 / 10$ & $07 / 08$ & $08 / 09$ & $09 / 10$ & $07 / 08$ & $08 / 09$ & $09 / 10$ \\
\hline \multicolumn{10}{|l|}{ Regulator } \\
\hline With & 159 & 146 & 183 & 132 & 119 & $131 \mathrm{~b}$ & $26 \mathrm{a}$ & $26 \mathrm{a}$ & $52 \mathrm{a}$ \\
\hline Without & 151 & 137 & 189 & 134 & 121 & $144 \mathrm{a}$ & $17 \mathrm{~b}$ & $15 \mathrm{~b}$ & $45 \mathrm{~b}$ \\
\hline LSD & 16.4 & - & 11.9 & 16.1 & - & 8.5 & 2.7 & 3.2 & 5.8 \\
\hline \multicolumn{10}{|c|}{$\mathrm{N}$ doses $\left(\mathrm{kg} \mathrm{ha}^{-1}\right)$} \\
\hline 0 & 158 & $118^{1}$ & $163^{2}$ & 136 & $104^{3}$ & $127^{4}$ & 23 & $14^{5}$ & $36^{6}$ \\
\hline 40 & 151 & 136 & 191 & 129 & 113 & 142 & 21 & 23 & 49 \\
\hline 80 & 153 & 155 & 195 & 130 & 133 & 147 & 23 & 23 & 49 \\
\hline 120 & 157 & 155 & 194 & 137 & 131 & 135 & 21 & 23 & 60 \\
\hline \multicolumn{10}{|l|}{ F test } \\
\hline $\mathrm{R}$ & $0.92^{\mathrm{ns}}$ & $2.69^{\mathrm{ns}}$ & $1.34^{\mathrm{ns}}$ & $0.03^{\mathrm{ns}}$ & $0.20^{\mathrm{ns}}$ & $11.18^{* *}$ & $49.71 * *$ & $53.01 * *$ & $6.39^{*}$ \\
\hline
\end{tabular}


continuation

\begin{tabular}{lccccccccc}
$\mathrm{N}$ & $0.22^{\text {ns }}$ & $10.10^{* *}$ & $7.35^{* *}$ & $0.26^{\text {ns }}$ & $9.17^{* *}$ & $4.27^{*}$ & $1.00^{\text {ns }}$ & $8.25^{* *}$ & $12.53^{* *}$ \\
$\mathrm{R} \times \mathrm{N}$ & $0.14^{\text {ns }}$ & $1.09^{\text {ns }}$ & $1.84^{\text {ns }}$ & $0.13^{\text {ns }}$ & $0.49^{\text {ns }}$ & $2.19^{\text {ns }}$ & $0.13^{\text {ns }}$ & $3.10^{\text {ns }}$ & $2.15^{\text {ns }}$ \\
\hline $\mathrm{CV}(\%)$ & 14.44 & 11.07 & 8.68 & 16.44 & 10.85 & 8.42 & 16.51 & 20.85 & 16.42 \\
\hline
\end{tabular}

Mean values followed by the same letters are equivalent, based on the Tukey test at $5 \%$ of probability.

ns - not significant, * and $* *$ significant at $5 \%$ and $1 \%$ of probability, respectively. LSD - least significant difference by Tukey test.

(1) $\hat{y}=121.95+0.3191 x\left(R^{2}=0.88\right)$.

(2) $\hat{y}=163.880+0.7894 x-0.0045 x^{2}\left(R^{2}=0.97\right)$.

(3) $\hat{y}=105.1875+0.2516 x\left(R^{2}=0.86\right)$.

(4) $\hat{y}=126.9153+0.5658 x-0.0042 x^{2}\left(R^{2}=0.99\right)$.

(5) $\hat{y}=14.8187+0.2189 x-0.0013 x^{2}\left(R^{2}=0.89\right)$.

(6) $\hat{y}=37.5444+0.1802 x\left(R^{2}=0.88\right)$.

In the second year, the total number of spikelets and full spikelets responded to the increase of $\mathrm{N}$ in topdressing, while for the number of empty spikelets, the onset of the decrease occurred following the application of $84 \mathrm{~kg} \mathrm{ha}^{-1}$ of $\mathrm{N}$ (Table 5). Owing to the fact that there was an increase in leaf $\mathrm{N}$ with increasing $\mathrm{N}$ dose, it can be inferred that the plants were better nourished and, consequently, adequately supplied the demand for better formation and filling of the spikelets. Similar responses were reported by Boldieri et al. (2010), Artigiani et al. (2012), and Goes et al. (2016b). In the third year, for both the total number of spikelets and filling of the spikelets, the quadratic function was adjusted to the $\mathrm{N}$ dose, presenting higher numbers with the maximum doses of 87 and $67 \mathrm{~kg} \mathrm{ha}^{-1}$ of N, respectively, while there was a linear increase in empty spikelets with the increase of $\mathrm{N}$. In the second year, the rice plants presented greater potential for producing panicles when compared with the third year (Table 4). In the third year, there was more accumulated precipitation and better distribution (Figure 1C), indicating that there were more cloudy days and, consequently, lower solar radiation incidence in relation to the second year (Figure 1B). Meirelles et al. (2019) reported that lower incidence of solar radiation reduces the photosynthetic process and leads to a decrease in the number of panicles $\mathrm{m}^{-2}$ in rice plants. Owing to the greater formation of panicles in the present study, there was less formation of spikelets per panicle, indicating possible competition within the plant for photoassimilates. Thus, there was a higher demand for $\mathrm{N}$ in the second year to supply the greater formation and filling of spikelets.

For the average of the three years of the 100-grain mass and only the first year of the productivity of rice grains showed an increase of about $9 \%$ and $12 \%$, respectively, with application of the regulator (trinexapac-ethyl). The use of the regulator favored the reduction of plant height and, consequently, reduced lodging. As a physiological response, instead of draining photoassimilates for growth, the plant might have directed them to the filling of the spikelets, resulting in greater mass during the three years of study and higher grain yield in the first year. Castilho et al. (2012) verified a 15\% increase in the 100-grain mass with the application of trinexapac-ethyl in upland rice irrigated by sprinkler. Nascimento et al. (2009), in a study of five trinexapac-ethyl doses $(0,75,150,225$, and $300 \mathrm{~g} \mathrm{ha}^{-1}$ ) and three application times (tillering, between tillering and floral differentiation, and floral differentiation), achieved an $18 \%$ increase in rice yield with the application of $150 \mathrm{~g} \mathrm{ha}^{-1}$ of the regulator at the time of floral differentiation. Arf et al. (2012), studying doses of trinexapac-ethyl in different upland rice cultivars, verified that between the doses of 0 and $150 \mathrm{~g} \mathrm{ha}^{-1}$ of the regulator, there was a $14 \%$ increase in the 100 -grain weight and $53 \%$ in grain yield.

In the second and third year, the increase in $\mathrm{N}$ intake by fertilization caused a decrease in the 100-grain mass (Table 6). The explanation for this 
decrease might be related to the increase in the total production of spikelets per panicle (Table 5), which might have promoted competition for nutrients for mass gain. Artigiani et al. (2012) also observed a reduction in 100-grain mass of rice owing to an increase in the supply of $\mathrm{N}$, and reported that this might have occurred because of the lack of sufficient carbohydrates for the mass gain of a larger number of spikelets. Other studies have also described the reduction of grain mass by the addition of nitrogen (BUZETTI et al., 2006; NASCIMENTO et al., 2013; FAGERIA; OLIVEIRA, 2014; GOES et al., 2016a; LACERDA; NASCENTE, 2016; CONTRERAS et al., 2017).

Table 6. Average values of 100-grain mass and yield obtained in upland rice with growth regulator and nitrogen doses. Selvíria (MS), 2007/08, 2008/09, and 2009/10.

\begin{tabular}{lcccccc}
\hline \multirow{2}{*}{ Treatments } & \multicolumn{3}{c}{ 100-grain mass $(\mathrm{g})$} & \multicolumn{3}{c}{ Yield $\left(\mathrm{kg} \mathrm{ha}^{-1}\right)$} \\
\cline { 2 - 7 } Regulator & $07 / 08$ & $08 / 09$ & $09 / 10$ & $07 / 08$ & $08 / 09$ & $09 / 10$ \\
With & & & & & & \\
Without & $2.19 \mathrm{~b}$ & $2.77 \mathrm{~b}$ & $2.61 \mathrm{~b}$ & $3,694 \mathrm{~b}$ & 5,825 & 4,985 \\
\hline LSD & $2.39 \mathrm{a}$ & $3.05 \mathrm{a}$ & $2.79 \mathrm{a}$ & $4,144 \mathrm{a}$ & 5,370 & 5,208 \\
\hline $\mathrm{N}$ doses $\left(\mathrm{kg} \mathrm{ha}^{-1}\right)$ & 0.12 & 0.11 & 0.17 & 404.11 & - & 690.53 \\
0 & & & & & & \\
40 & 2.36 & $3.07^{1}$ & $2.87^{2}$ & 4,026 & $4,623^{3}$ & $4,605^{4}$ \\
80 & 2.23 & 3.01 & 2.62 & 3,517 & 5,566 & 4,853 \\
120 & 2.31 & 2.83 & 2.78 & 4,131 & 5,738 & 5,315 \\
\hline F test & 2.26 & 2.73 & 2.53 & 4,002 & 6,462 & 5,615 \\
R & & & & & & \\
$\mathrm{N}$ & $11.97^{* *}$ & $26.79^{* *}$ & $4.82^{*}$ & $5.36^{*}$ & $1.33^{\text {ns }}$ & $0.451^{\text {ns }}$ \\
R x N & $0.91^{\text {ns }}$ & $8.87^{* *}$ & $3.56^{*}$ & $1.98^{\text {ns }}$ & $3.70^{*}$ & $3.37^{*}$ \\
\hline CV $(\%)$ & $0.60^{\text {ns }}$ & $2.85^{\text {ns }}$ & $0.35^{\text {ns }}$ & $2.7^{\text {ns }}$ & $1.51^{\text {ns }}$ & $1.87^{\text {ns }}$ \\
\hline
\end{tabular}

Mean values followed by the same letters are equivalent, based on the Tukey test at $5 \%$ of probability.

ns - not significant, * and $* *$ significant at $5 \%$ and $1 \%$ of probability, respectively. LSD - least significant difference by Tukey test.

(1) $\hat{y}=3,093-0.0031 x\left(R^{2}=0.97\right)$.

(2) $\hat{y}=2,828-0.0022 x\left(R^{2}=0.53\right)$.

(3) $\hat{y}=4,743+14.226 x\left(R^{2}=0.94\right)$.

(4) $\hat{y}=4,573+8.727 x\left(R^{2}=0.99\right)$.

Increasing $\mathrm{N}$ rates caused a linear increase in grain yield of rice in the last two years of the study (Table 6). According to equations 3 and 4, in the average of the two years, there was an increase of approximately $0.25 \%$ in the yield of rice grains for each $\mathrm{kg}$ of $\mathrm{N}$ applied, thereby increasing productivity by $30 \%$ with the application of $120 \mathrm{~kg}$ $\mathrm{ha}^{-1}$ of $\mathrm{N}$. The application of the maximum dose of $\mathrm{N}$ in 2008/2009 and 2009/2010 resulted in an average increase in the total number of spikelets and full spikelets per panicle of $25 \%$ and $16 \%$, respectively
(Table 5). Thus, these two components may have favored an increase in the grain yield of rice owing to the increase in $\mathrm{N}$ supply. Additionally, in the Cerrado environment, several studies have reported increased productivity of upland rice grains owing to the contribution of $\mathrm{N}$ via fertilizer (CAZETTA et al., 2008; ARTIGIANI et al., 2012; LACERDA; NASCENTE, 2018).

In the first year, the application of the growth regulator favored a higher milling yield, higher rice 
head yield, and decreased percentage of broken grains (Table 7). The explanation for this was that the application of the regulator eliminated lodging of the plants (Table 2); the grains did not remain in contact with the soil, similar to the grains in the non-regulator treatment, and allowed conditions of humidity in the appropriate grains at the time of evaluation. In the second year, the reverse occurred, with the exception of the broken grains. Castilho et al. (2012), studying the use of trinexapac-ethyl associated with different densities of upland rice seeding, observed exactly the same results with the application of the regulator.

With regard to the application of $\mathrm{N}$ doses, in the third year there was a linear reduction in rice head yield, whereas there was a linear increase in broken grains (Table 7). This result can be attributed to the reduction in the 100-grain mass of the rice and the increase in the number of empty spikelets, culminating in grains with less mechanical resistance. The percentage of broken grains in the first year decreased with increasing doses of $\mathrm{N}$.

Table 7. Average values of milling yield, head yield, and broken grains obtained in upland rice with growth regulator and nitrogen doses. Selvíria (MS), 2007/08, 2008/09, and 2009/10.

\begin{tabular}{lccccccccc}
\hline \multirow{2}{*}{ Treatments } & \multicolumn{3}{c}{ Milling yield (\%) } & \multicolumn{3}{c}{ Head yield (\%) } & \multicolumn{3}{c}{ Broken grains (\%) } \\
\cline { 2 - 10 } & $07 / 08$ & $08 / 09$ & $09 / 10$ & $07 / 08$ & $08 / 09$ & $09 / 10$ & $07 / 08$ & $08 / 09$ & $09 / 10$ \\
\hline Regulator & & & & & & & & & \\
With & $65.63 \mathrm{~b}$ & $72.8 \mathrm{a}$ & 73.41 & $53.79 \mathrm{~b}$ & $71.2 \mathrm{a}$ & 71.03 & $12.62 \mathrm{a}$ & 3.27 & 2.38 \\
Without & $68.16 \mathrm{a}$ & $71.5 \mathrm{~b}$ & 74.09 & $59.58 \mathrm{a}$ & $69.0 \mathrm{~b}$ & 71.44 & $8.59 \mathrm{~b}$ & 3.25 & 2.66 \\
\hline LSD & 1.47 & 1.92 & 1.21 & 2.11 & 1.45 & 1.11 & 1.05 & - & 0.42 \\
\hline $\mathrm{N}$ doses $\left(\mathrm{kg} \mathrm{ha}^{-1}\right)$ & & & & & & & & & \\
0 & 66.81 & 72.1 & 74.18 & 57.20 & 70.0 & $72.00^{1}$ & $11.24^{2}$ & 2.91 & $2.18^{3}$ \\
40 & 67.15 & 72.4 & 74.01 & 55.80 & 70.1 & 71.44 & 11.30 & 3.55 & 2.58 \\
80 & 67.01 & 71.9 & 73.88 & 57.21 & 70.0 & 71.66 & 9.80 & 3.02 & 2.21 \\
120 & 66.60 & 72.3 & 72.94 & 56.53 & 70.2 & 69.84 & 10.08 & 3.55 & 2.88 \\
\hline F test & & & & & & & & & \\
R & $12.82^{* *}$ & $9.54^{* *}$ & $1.40^{\text {ns }}$ & $32.39^{* *}$ & $10.25^{* *}$ & $0.57^{\text {ns }}$ & $64.35^{* *}$ & $0.004^{\text {ns }}$ & $1.96^{\text {ns }}$ \\
$\mathrm{N}$ & $0.12^{\text {ns }}$ & $0.29^{\text {ns }}$ & $0.91^{\text {ns }}$ & $0.44^{\text {ns }}$ & $0.01^{\text {ns }}$ & $3.20^{*}$ & $2.39^{*}$ & $1.14^{\text {ns }}$ & $4.56^{*}$ \\
R x N & $0.33^{\text {ns }}$ & $1.11^{\text {ns }}$ & $1.28^{\text {ns }}$ & $0.66^{\text {ns }}$ & $0.13^{\text {ns }}$ & $1.24^{\text {ns }}$ & $0.45^{\text {ns }}$ & $1.09^{\text {ns }}$ & $1.12^{\text {ns }}$ \\
\hline CV $(\%)$ & 3.00 & 1.74 & 2.23 & 5.07 & 2.82 & 2.13 & 13.41 & 27.47 & 22.59 \\
\hline
\end{tabular}

Mean values followed by the same letters are equivalent, based on the Tukey test at $5 \%$ of probability.

ns - not significant, * and ** significant at $5 \%$ and $1 \%$ of probability, respectively. LSD - least significant difference by Tukey test.

(1) $\hat{y}=72.1738-0.0157 x\left(R^{2}=0.71\right)$.

(2) $\hat{\mathrm{y}}=11.3513-0.01247 \mathrm{x}\left(\mathrm{R}^{2}=0.68\right)$.

(3) $\hat{y}=2.1538+0.0060 x\left(R^{2}=0.53\right)$.

It is worth noting that in the present study, despite some differences in the components of the milling yield, mainly owing to the application of the growth regulator, the values obtained for milling yield, head yield, and broken grains yield were excellent for all treatments. In the last two years of cultivation, all the treatments presented excellent grain quality with a head yield greater than $60 \%$. Even in the first year of cultivation, when the treatments showed a head yield of less than $60 \%$, these values were quite expressive, since the values found were much higher than those required for the commercialization of the product at the national level, where a value of $40 \%$ or more is considered an adequate head grain yield (FORNASIERI FILHO; FORNASIERI, 2006). 


\section{Conclusion}

The application of $150 \mathrm{~g} \mathrm{ha}^{-1}$ of trinexapacethyl at the flower differentiation stage reduced plant height and lodging. In addition, this treatment promoted increased 100-grain mass.

The use of $\mathrm{N}$ doses in topdressing increased plant height and grain yield.

The plant growth regulator interfered little in the milling yield of upland rice.

Nitrogen fertilization in the topdressing did not significantly interfere with the milling yield of upland rice irrigated by sprinkler.

\section{Acknowledgements}

The authors would like to thank the São Paulo Research Foundation (FAPESP - Registry number: 2007/58119-2) for financial support.

\section{References}

ALVAREZ, R. C. F.; CRUSCIOL, A. A. C.; NASCENTE, A. S. Produtividade de arroz de terras altas em função de reguladores de crescimento. Revista Ceres, Viçosa, MG, v. 61, n. 1, p. 42-49, 2014. DOI:10.1590/S0034737X2014000100006

ARF, O.; NASCIMENTO, V.; RODRIGUES, R. A. F.; ALVAREZ, R. C. F.; GITTI, D. C.; SÁ, M. E. Uso de etiltrinexapac em cultivares de arroz de terras altas. Pesquisa Agropecuária Tropical, Goiânia, v. 42, n. 2, p. 150-158, 2012. DOI: $10.1590 / \mathrm{S} 1983-40632012000200008$

ARF, O.; RODRIGUES, R. A. F.; NASCENTE, A. S.; LACERDA, M. C. Adubação antecipada de nitrogênio na cultura do arroz de terras altas sob plantio direto. Revista de Ciências Agrárias/Amazonian Journal of Agricultural and Environmental Sciences, Belém, v. 58, n. 1, p. 6-13, 2015. DOI: $10.4322 /$ rca. 1625

ARTIGIANI, A. C. C. A.; CRUSCIOL, C. A. C.; ARF, O.; ALVAREZ, R. C. F.; NASCENTE, A. S. Produtividade e qualidade industrial do arroz de terras altas em função da disponibilidade hídrica e adubação. Pesquisa Agropecuária Tropical, Goiânia, v. 42, n. 3, p. 340-349, 2012. DOI: $10.1590 / \mathrm{S} 1983-40632012000300011$

BARRETO, J. H. B.; SOARES, I.; PEREIRA, J. A.; BEZERRA, A. M. M.; DEUS, J. A. L. Yield performance of upland rice cultivars at different rates and times of nitrogen application. Revista Brasileira de Ciência do Solo, Viçosa, MG, v. 36, n. 2, p. 475-483, 2012. DOI: 10.1590/S0100-06832012000200017

BASUCHAUDHURI, P. (Ed.). Nitrogen metabolism in rice. Boca Raton/New York/London: CRC Press, 2016. 259 p.

BOLDIERI, F. M.; CAZETTA, D. A.; FORNASIERI FILHO, D. Adubação nitrogenada em cultivares de arroz de terras altas. Revista Ceres, Viçosa, MG, v. 57, n. 3, p. 421-428, 2010. DOI: 10.1590/S0034737X2010000300020

BRESEGHELLO, F.; CASTRO, E. M.; MORAIS, O. P. Cultivares de arroz. In: BRESEGHELLO, F.; STONE, L. F. Tecnologia para arroz de terras altas. Santo Antônio de Goiás: EMBRAPA Arroz e Feijão, 1998. p. 41-53.

BUZETTI, S.; BAZANINI, G. C.; FREITAS, J. G.; ANDREOTTI, M.; ARF, O.; SÁ, M. E.; MEIRA, F. A. Resposta de cultivares de arroz a doses de nitrogênio e do regulador de crescimento cloreto de clormequat. Pesquisa Agropecuária Brasileira, Brasília, v. 41, n. 12, p. 17311737, 2006. DOI: 10.1590/S0100-204X2006001200007

CANTARELla, H.; RAIJ, B. V.; CAMARGO, C. E. O. Cereais. In: RAIJ, B. V.; CANTARELLA, H.; QUAGgIO, J. A.; FURLANI, A. M. C. (Ed.). Recomendações de calagem e adubação para o Estado de São Paulo. Campinas: IAC, 1997. p. 45-71. (Boletim técnico, 100).

CASTILHO, J. S.; ARF, O.; GITTI, D. C.; KOGA, P. S. L.; RODRIGUES, R. A. R. Regulador vegetal e densidades de semeadura na cultura do arroz de terras altas. Revista Agrarian, Dourados, v. 5, n. 8, p. 337-348, 2012.

CAZETTA, D. A.; ARF, O.; BUZETTI, S.; SÁ, M. E.; RODRIGUES, R. F. Desempenho do arroz de terras altas com a aplicação de doses de nitrogênio e em sucessão às culturas de cobertura do solo em sistema de plantio direto. Bragantia, Campinas, v. 67, n. 2, p. 471-479, 2008. DOI: $10.1590 / \mathrm{S} 0006-87052008000200023$

CONTRERAS, H. A. S.; BARZAN, R. R.; CONTRERAS, M. S.; BRITO, O. R. Growth, yield and agronomic efficiency of rice (Oryza sativa L.) cv. IAPAR 117 affected by nitrogen rates and sources. Acta Agronómica, Palmira, v. 66, n. 4, p. 558-565, 2017. DOI: 10.15446/acag.v66n4.59101

DAVIES, P. J. Plant hormones physiology biochemistry and molecular biology. $2^{\text {th }}$ ed. Dordrecht: Klumer Academic Publishes, 1995. 823 p.

FAGERIA, N. K. Yield physiology of rice. Journal of Plant Nutrition, Philadelphia, v. 30, n. 6, p. 843-879, 2007. DOI: $10.1080 / 15226510701374831$ 
FAGERIA, N. K.; MOREIRA, A.; MORAES, L. A. C.; MORAES, M. Nitrogen uptake and use efficiency in upland rice under two nitrogen sources. Communications in Soil Science and Plant Analysis, Philadelphia, v. 45, n. 4, p. 461-469, 2014. DOI: 10.1080/00103624.2013.861907

FAGERIA, N. K.; OLIVEIRA, J. P. Nitrogen, phosphorus and potassium interactions in upland rice. Journal of Plant Nutrition, Philadelphia, v. 37, n. 10, p. 1586-1600, 2014. DOI: $10.1080 / 01904167.2014 .920362$

FERRARI, S.; NAKAYAMA, T.; FERRARI, J. V. Uso de regulador de crescimento e doses de nitrogênio no desenvolvimento e produtividade de arroz de terras altas. Revista Cientifica ANAP Brasil, v. 10, n. 19, p. 15-26, 2017. DOI: $10.17271 / 19843240101920171646$

FORNASIERI FILHO, D.; FORNASIERI, J. L. Manual da cultura do arroz. Jaboticabal: FUNEP, 2006. 589 p.

FREIRE, F. M.; VASCONCELLOS, C. A.; FRANÇA, G. E. Manejo da fertilidade do solo em sistema plantio direto. Informe Agropecuário, Belo Horizonte, v. 22, n. 208, p. 49-56, 2001.

GITTI, D. C.; ARF, O.; PORTUGAL, J. R.; CORSINI, D. C. D. C.; RODRIGUES, R. A. F.; KANEKO, F. H. Coberturas vegetais, doses de nitrogênio e inoculação de sementes com Azospirillum brasilense em arroz de terras altas no sistema plantio direto. Bragantia, Campinas, v. 71 , n. 4 , p. $509-517,2012$. DOI: 10.1590/S000687052013005000002

GOES, R. J.; RODRIGUES, R. A. F.; TAKASU, A. T.; ARF, O. Inoculação com Azospirillum brasilense, manejo de água e adubação nitrogenada no arroz de terras altas. Revista Agrarian, Dourados, v. 9, n. 33, p. 254-262, 2016a.

GOES, R. J.; RODRIGUES, R. A. F.; TAKASU, A. T.; ARF, O. Manejo do nitrogênio em cobertura no arroz de terras altas em sistema plantio direto. Revista Agrarian, Dourados, v. 9, n. 31, p. 11-18, 2016 b.

LACERDA, M. C.; NASCENTE, A. S. Effects of row spacing and nitrogen topdressing fertilization on the yield of upland rice in a no-tillage system. Acta Scientiarum. Agronomy, Maringá, v. 38, n. 4, p. 493-502, 2016. DOI: 10.4025/actasciagron.v38i4.30855

LIU, X.; WANG, H.; ZHOU, J.; HU, F.; ZHU, D.; CHEN, $\mathrm{Z}$.; LIU, Y. Effect of $\mathrm{N}$ fertilization pattern on rice yield, $\mathrm{N}$ use efficiency and fertilizer-N fate in the Yangtze River Basin, China. PLOS ONE, San Francisco, v. 11, n. 11, p. 1-20, 2016. DOI: 10.1371/journal.pone.0166002

LOPES, R. A.; BUZETTI, S.; TEIXEIRA FILHO, M. C. M.; BENETT, C. G. S.; ARF, M. V. Doses, fontes e épocas de aplicação de nitrogênio em arroz de terras altas cultivado em sistema de semeadura direta. Revista Caatinga, Mossoró, v. 26, n. 4, p. 79-87, 2013.

MEIRELLES, F. C.; ARF, O.; GARCIA, N. F. S.; TAKASU, A. T.; BUZO, F. S.; CORSINI, D. C. D. C.; MARTINS, J. T.; ANDRADE, J. A.; PORTUGAL, J. R. Performance of upland rice cultivars at different sowing times: an alternative for crop rotation in low altitude Cerrado region, Brazil. Australian Journal of Crop Science, Lismore, v. 13, n. 2, p. 242-250, 2019. DOI: 10.21475/ajcs.19.13.02.p1312

NA, C. I.; HAMAYUN, M.; KHAN, A. L.; KIM, Y. H.; CHOI, K. I.; KANG, S. M.; KIM, S. I.; KIM, J. T.; WON, J. G.; LEE, I. J. Influence of prohexadionecalcium, trinexapac-ethyl and hexaconazole on lodging characteristic and gibberellin biosynthesis of rice (Oryza sativa L.). African Journal of Biotechnology, Nairobi, v. 10, n. 61, p. $13097-13106,2011$. DOI: $10.5897 /$ AJB11.746

NASCIMENTO, V.; ARF, O.; ALVES, M. C.; BONINI, C. S. B.; KANEKO, F. H.; TEIXEIRA FILHO, M. C. M. Mecanismos de abertura do sulco e da adubação nitrogenada em arroz de terras altas. Revista Ceres, Viçosa, MG, v. 60, n. 6, p. 802-810, 2013. DOI: 10.1590/ S0034-737X2013000600008

NASCIMENTO, V.; ARF, O.; SILVA, M. G.; BINOTTI, F. F. S.; RODRIGUES, R. A. F.; ALVAREZ, R. C. F. Uso do regulador de crescimento etil-trinexapac em arroz de terras altas. Bragantia, Campinas, v. 68, n. 4, p. 921-929, 2009. DOI: $10.1590 /$ S0006-87052009000400012

PORTUGAL, J. R.; PERES, A. R.; RODRIGUES, R. A. F. Aspectos climáticos no feijoeiro. In: ARF, O.; LEMOS, L. B.; SORATTO, R. P.; FERRARI, S. (Ed.). Aspectos gerais da cultura do feijão Phaseolus vulgaris L. Botucatu: FEPAF, 2015a. p. 65-75.

PORTUGAL, J. R.; TARSITANO, M. A.; PERES, A. R.; ARF, O.; RODRIGUES, R. A. F. Análise econômica do cultivo do arroz de terras altas com e sem irrigação. Revista Agrarian, Dourados, v. 8, n. 27, p. 104-110, $2015 b$.

REIS, H.P. G.; BARCELOS, J.P. Q.; FURLANI JUNIOR, E.; SANTOS, E. F.; SILVA, V. M.; MORAES, M. F.; PUTTI, F. F.; REIS, A. R. Agronomic biofortification of upland rice with selenium and nitrogen and its relation to grain quality. Journal of Cereal Science, London, v. 79, n. 1 , p. 508-515, 2018. DOI: 10.1016/j.jcs.2018.01.004

SANTOS, H. G.; JACOMINE, P. K. T.; OLIVEIRA, V. A.; LUMBRERAS, J. F.; COELHO, M. R.; ALMEIDA, J. A.; CUNHA, T. J. F.; OLIVEIRA, J. B. Sistema brasileiro de classificação de solos. Brasília: EMBRAPA, 2013. $353 \mathrm{p}$. 
SILVA, C. A.; VALE, F. R.; ANDERSON, S. J.; KOBAL, A. R. Mineralização de nitrogênio e enxofre em solos brasileiros sob influência da calagem e fósforo. Pesquisa Agropecuária Brasileira, Brasília, v. 34, n. 9, p. 16791689, 1999. DOI: 10.1590/S0100-204X1999000900019

TAIZ, L.; ZEIGER, E.; MOLLER, I. M.; MURPHY, A. Fisiologia e desenvolvimento vegetal. 6. ed. Porto Alegre: Artmed, 2017. 888 p. 